\author{
Г.К. Қазыбек \\ Әл-Фараби атындағы Қазақ ұлттық университеті, Қазақстан, Алматы қ. \\ e-mail: kazybek_68@mail.ru \\ ТӘУЕАСІЗ ҚАЗАҚСТАНААҒЫ \\ АУААРМАТАНУ АХУААЫ
}

Мақалада Тәуелсіз Қазақстандағы аударматану ғылымының даму тарихы, аударматанудың өзекті мәселелері, жетістіктері мен кемшіліктері жан-жақты қарастырылады. Аударма қиын да қызықты өнер. Аударма әркімнің қолынан келе бермейтін де қиын да жауапты іс. Мақалада аударматану ғылымы тәуелсіздік жылдарында қалай дамылы, аудармаға байланысты қандай ғылыми зерттеулер пайда болды т.б. тақырыптарға шолу жасалады. Әл-Фараби атындағы Қазақ ұлттық университеті ғалымдарының аударматану ғылымына қосқан үлестері нақты көрсетіледі. Аударма ғылымын өркендетуге арналған бірнеше ұсыныстар да беріледі.

Елбасы Н.Ә. Назарбаевтың жолдаулары мен мақалаларындағы аударма туралы айтылған пікірлері мен Тәуелсіздік алғаннан кейінгі жарияланған ғылыми еңбектер, көркем әдебиет нұсқалары сараланады, аудармашылар туралы мәліметтер беріледі.

Тәуелсіздік алғаннан кейін жоғары оқу орындарының арасында ең бірінші болып аударма мамандығының Әл-Фараби атындағы Қазақ ұлттық университетінде ашылғандығы, қазіргі кездегі аударма мамандығының ахуалы туралы сөз болады.

Университет жанынан «Көркем аударма орталығын» ашу ұсынысының маңыздылығы көрсетіледі. Аударманың түрлері көп, дегенмен көркем аударманың аударылу сапасын тексеретін, оның оқырманға беретін рухани құндылығын анықтайтын бірлестік те, қауымдастық та жоқ, екенін ескерсек, осындай одақтың университет жанынан құрылуы нұр үстіне нұр болар еді деп ойлаймыз.

Түйін сөздер: аударма, аударматану, түпнұсқа, мәтін, аударма бірліктері, аударма нұсқа.

\author{
G.K.Kazybek \\ Al-Farabi Kazakh National University, Kazakhstan, Almaty \\ e-mail: kazybek_68@mail.ru

\section{Translation Studies in Independent Kazakhstan}

The article comprehensively examines the history of the development of Translation Studies in the period of independence, its current problems, achievements and shortcomings. Translation is a complex and interesting art form. Translation is a challenging and responsible task that is not available to everyone. The article provides an overview of the development of Translation Studies as a science over the years of independence, scientific articles in this industry. The contribution of scientists of the Al-Farabi Kazakh National University to the Science of Translation is mentioned. Several recommendations for the improvement and development of Translation Studies are given.

The statements of the head of state N.A. Nazarbayev about Translation Studies in his speech and articles, scientific works, works of art published after gaining independence are analyzed, information about translators is provided.

The article informs that after gaining independence, Al-Farabi Kazakh National University became one of the first higher educational institutions to open the specialty "Translation Studies", as well as the current state of this specialty.

The importance of the proposal to open the "Center for Literary Translation" at the university is indicated. There are many types of translation, however, considering the fact that at the current stage there is no association or community capable of evaluating the quality of translation of works of fiction, its moral value and impact on the reader, we think it would be great to create such a community at a university.

Key words: translation, translation studies, original, text, translation units, translation option. 


\section{Г.Қ. Қазыбек \\ Казахский национальный университет имени аль-Фараби, Казахстан, г. Алматы e-mail: kazybek 68@mail.ru}

\section{Переводоведение в Независимом Казахстане}

В статье всесторонне рассматриваются история развития переводоведения в период независимости, ее актуальные проблемы, достижения и недостатки. Перевод - сложный и интересный виА искусства. Перевод - непростое, ответственное дело, которое доступно далеко не каждому. В статье приводится обзор развития переводоведения как науки за годы независимости, научных статей по данной сфере. Упоминается вклаА ученых Казахского национального университета имени аль-Фараби в науку переводоведения. Приводятся несколько рекомендаций по улучшению и развитию переводоведения.

Анализируются высказывания Главы государства Н.А. Назарбаева о переводоведении в посланиях и статьях, научные работы, художественные труды, опубликованные после обретения независимости, дается информация о переводчиках.

Статья информирует о том, что после обретения независимости Казахский национальный университет имени аль-Фараби стал одним из первых высших учебных заведений, открывшим специальность «Переводческое дело», а также о нынешнем положении данной специальности.

Указывается значимость предложения открытия «Центра художественного перевода» при университете. Существуют множество видов перевода, однако, тем не менее, учитывая, что на данном этапе нет ни объединения, ни сообщества, способного оценить качество перевода художественных работ, его нравственную ценность и влияние на читателя, считаем, что было бы замечательно создать такое сообщество при университете.

Кмючевые слова: перевод, переводоведение, оригинал, текст, единицы перевода, вариант перевода.

\section{Kipicne}

Аударма өнері қызықты да қиын ғылым екендігі бұрыннан белгілі. Аударматану ғылымының қайнар көзі сонау ертеден келе жатыр. Аударманың тарихы, оның негізгі кезеңдері туралы сан алуан ғылыми мақалалар мен зерттеулер, диссертациялар жарияланған.

Бұл мақалада біз Қазақстанның тәуелсіздік алған жылдарынан бастап аударма ғылымы қалай дамыды, негізгі аудармашылары кімдер болды, аудармаларының сапасы, ондағы кемшіліктер мен жетістіктерді талдауды жөн көрдік. Ең алдымен, әл-Фараби атындағы Қазақ ұлттық университеті ғалымдарының аударма ғылымының дамуына қосқан үлестері жайлы айтуды басты мақсат етіп отырмыз.

Тәуелсіздік жылдары ғылым мен мәдениеттің, әдебиет пен сынның т.б. даму қарқыны жаңа серпініммен, жаңа белестерді бағындырумен ерекшеленеді. Аударма ғылымы да дами түсті. Әдебиет сыншысы С.Әшімбаев: «Бүгінгі аударма - көркем ойдың алтын көпірі», - деп айтқандай Тәуелсіз Қазақстанды бүкіл әлем тани бастады. [1,31]. Шетел әдебиетінің алтын қорына кіретін әдебиеттер қазақ тіліне жаппай аударыла бастаса, қазақ халқының әдебиетінің көрнекті өкілдерінің шығармалары өзге тілдерге аударыла бастады. Дәл осы уақытта аудармашы мамандарына сұраныс арта түсті.
Тәуелсіздік алғаннан кейін жоғары оқу орындарының арасында ең бірінші болып аударма мамандығының біздің университетте ашылғандығын мақтанышпен айта аламыз. Сондай-ақ мақалада қазақ ақын-жазушыларының орыс тіліне аударылу тарихына да тоқталып, талдаулар жүргіземіз. Мақалада неліктен орыс тіліне аударылған шығармаларды ғана арқау етуіміздің басты себебі, орыс тілі арқылы өзге тілдерге аударылуы тезірек болды. Аударма ғылымында сатылы аударма деген тәсіл бар. Қазақ - орыс - ағылшын деп ары қарай өзге тілдерге аударыла береді. Бұл аудармаларды сатылы аударма деп атаймыз.

Әл-Фараби атындағы ҚазҰУ ғалымдары да Тәуелсіз Қазақстандағы аударма ғылымының өркендеуіне үлес қосып келеді. Атап айтқанда, профессорлар С. Ашимханова, Ж. Дәдебаев, Э. Сүлейменова, Т. Есембеков, А. Жақсылықов, Ә. Тараков, доценттер С. Сейденова, Л. Мұсалы, Г. Акимбекова, Г. Сүлейменова, Г. Бекқожанова, T. Пшенина, Г. Айтжанова, Р. Таева мен PhD докторлары М.Аймағамбетова, Қ.Кенжеқанова, Ә.Жапарова сынды ғалымдар болашақ аудармашы мамандығының қыр-сырына үйретін білікті ұстаздар ғана емес, сонымен қатар аударма туралы монографиялар мен ғылыми кітаптардың, окулықтар мен оку кұралдардың авторлары. Сoнымен қатар, болашақ аудармашыларға аударманың қыр-сырын, аударманың түрлері мен 
тәсілдері т.б. үйрету саласында аянбай қызмет атқарып келеді.

\section{Материал және әдістер}

Ғылыми мақаланы жазу барысында біз салыстырмалы-салғастырмалы, сипаттамалы, түсіндіру әдістерін қолдандық. Негізгі материал ретінде Тәуелсіз Қазақстан жылдарында жарияланған аударма кітаптар, аударматану бойынша жазылған отандық және шетелдік ғылыми мақалалар мен ғылыми кітаптар, оқулықтар мен оқу құралдары, сөздіктер мен хрестоматиялар, анықтамалықтар алынды.

\section{Әдебиетке шолу}

Мақаланы жазу барысында көптеген әдебиеттерге шолу жасалынды, кейбір материалдар талданды, кейбір аудармалардың сапасы сараланды, негізгі ойлар мен қорытындылар айтылды. Ең алдымен мақаламызға арқау болған Елбасы Н.Ә. Назарбаевтың мақалалары, атап айтқанда, «Болашаққа бағдар: рухани жаңғыру», «Ұлы даланың жеті қыры». Сонымен қатар, М.Әуезов, С.Әшімбаев, И.Левый, Ә.Сатыбалдиев, С.Талжанов, 3.Тұрарбеков т.б. аудармаға байланысты пікірлері, 2013 жылы Мәскеу қаласындағы «Көркем әдебиет» баспасынан шыққан «Тәуелсіз Қазақстан: Қазіргі әдебиет антологиясы» деп аталатын үш томдық жинағы.

\section{Нәтижелер мен талқылау бөлімі}

Аударма ұғымы өте күрделі ұғымдардың бірі екендігі сөзсіз. Аударматану ғылымының көрнекті өкілі Ә.Сатыбалдиев айтқандай, аударма дегеніміз еріккеннің ісі емес екендігін басты назарда ұстауымыз қажет.[2,164] Аударма ғылым әрі өнер. Аударма қиын да қызықты. Аударматанушы ғалым И Левыйдың «Аудармашы енбегінің мақсаты түп бейнесі болмайтын тың туынды жасап шығу емес, түпнұсқаны түсіну, сақтау, жеткізу, ал аударманың мақсаты қайта туындату», - деп айтқан пікіріне келіспеске болмайды. Аударма әрқашанда халықтар, ұлттар арасындағы әлеуметтік, экономикалық, рухани, ғылыми қарым-қатынастың алмасу, айырбастаудың құралы, ел танудың құралы, достықтың, ынтымақтастықтың, тәжірибе-тағылым алмасудың дәнекері екендігі бұрыннан белгілі. Түпнұсқаның стильдік, тілдік ерекшеліктерін түгел ескере отырып, оның көркемдік- идеялық қасиеттерін толық жеткізу, әрі қазақша түсінікті етіп шығару. Осы екеуі ұштасқанда ғана аударма сәтті болады. Адамзат тарихында әрбір ұлт, әрбір қоғам алмасу, ауысу, араласу нәтижесінде өмір ағымы алға жылжиды, өседі, өркендейді. Яғни, өзінде жоқты өзгеден алады, білмейтінін үйренеді, білгенін басқаға үйретеді. Осындай ауысудың тиянақты тірегі - аударма. Осыған орай, А.Пушкин "аудармашылар - мәдениетті бір елден екінші елге тасымалдап жеткізетін почта аттары“ деген пікірінің маңыздылығын байқауымызға болады. Ал М.Т. Цицерон "аудару кезінде сөзді санамау керек, керісінше сөзді салмақтау керек“ деген екен. Белгілі ғалым Ш.Сәтбаеваның әдеби байланыс туралы: “Қай халықтың болмасын өнер жағынан дамуында әдеби байланыстар сол ұлт әдебиетінің өркен жая өсуіне, оның әлеуметтік ықпалының күшеюіне септігін тигізіп, сөз өнерінде көрінген халықтың рухани қалпын, арман-мүддесін, өмір тарихын басқа халықтардың даму тарихымен ұштастыруға, сөйтіп, олардың өзара бөлісуіне, бірін-бірі құрметтеп, достасуына денекер болады“, - деген пікір бүгін таңда да маңызын жойған жоқ.

2017 жылдың 12 сәуірінде Елбасы Н.Ә:Назарбаевтың Мемлекет басшысының «Болашаққа бағдар: рухани жаңғыру» атты мақаласы жарық көрді. [2] Елбасы Тәуелсіз Қазақстанның алдына қойылған негізгі міндеттерді атады. Осы міндеттердің ішінде аударма мәселесі де арнайы көтерілді. Мәселен: « Біздің әлеуметтік және гуманитарлық біліміміз ұзақ жылдар бойы бір ғана ілімнің аясында шектеліп, дүниеге бір ғана көзқараспен қарауға мәжбүр болдық»,дей келе аудармашыларға зор міндет жүктеді. Осы мақалада көтерілген мәселелерді орындау мақсатында «Жаңа гуманитарлық білім. Қазақ тіліндегі 100 жаңа оқулық» атты жоба жүзеге асырылды. Жобаны жүзеге асыру үшін Ұлттық аудару бюросы үкіметтік емес және коммерциялық емес ұйым түрінде құрылды. Жобаға үш жүзден аса маман қатысты. Әлемнің ең үздік 100 оқулығы қазақ тіліне аударылып, кемінде 10 мың данамен басылып шықты. Еліміздің барлық жоғары оқу орындарына таратылды. Аударма кітаптар мен оқулықтар қазақ оқырмандарының қолына тиді. Әрине, аудармалардың сапасы мен әдістәсілдеріне тоқталмаймыз. Айтайын дегеніміз, Елбасының көрегенділігінің арқасында аударматану ісі дами бастады. Шет тілдерінде жарық көрген туындылар тікелей қазақ тіліне аударыла бастады. Бұл аудармашылар үшін өте қуанышты жағдай. Бұл Тәуелсіз Қазақстандағы 
аударматану ғылымының үздіксіз дамып келе жатқандығының айқын көрінісі. Бір өкініштісі, 2020 жылдың аяғында бұл бюро өз жұмысын тоқтатты.

Елбасының «Төл тарихын білетін, бағалайтын және мақтан ететін халықтың болашағы зор болады деп сенемін. Өткенін мақтан тұтып, бүгінін нақты бағалай білу және болашаққа оң көзқарас таныту - еліміздің табысты болуының кепілі дегеніміз осы», деген пікірі аудармашыларға тікелей айтылған ой деп айтамыз. Себебі, тек қана аудармашылар халқымыздың небір құнды жәдігерлерін өзге тілдерге аудару арқылы шетел оқырмандарын қазақ елі мен тарихынан хабардар ете алады.

Елбасы Н.Ә. Назарбаевтың арнайы жарлығымен 2006 жылы іс қағаздарын жүргізуді кезең кезеңімен қазақ тілінде өткізу туралы Жарлығы жарияланды. [3] Осы кезден бастап аудармашылардың рөлі біршама көтерілді. Әсіресе, ілеспе аударма дами бастады. Дегенмен әзірге дейін кәсіби аудармашылар мектебі әлі де өз дәрежесінде қалыптаса алмай келеді. жоғары оқу орындарындағы ұстаздардың аударма оқулықтарының сапасын анықтайтын, кемшіліктерін көрсететін ұйым жоқтың қасы. Әлі де болса аударматану ғылымында кезек күттірмейтін, шешімі табылмаған өзекті мәселелердің бар екендігін де ашық айтуымыз керек.

Тәуелсіз Қазақстанда аударматану ғылымының тарихына, аударманың түрлері мен әдістеріне, әлем әдебиетінің қазақ оқырмандарының танысуынат.б.үкіметтарапынан дақолдау көрсетіліп келеді. Яғни, аудармашылардың рөлі артып келе жатқандығы даусыз.

Қазақстандааударматанумәселесінеарналған ғылыми оқу құралдарының авторлары да жыл санап көбейіп келеді. Бұл өте куантарлық жағдай. Мысалы, А.Алдашеваның «Аударматану: лингвистикалық және лингвомәдени мәселелер» [4], К.Әлпейісованың « Ілеспе аударма: таным мен тәжірибе» [5], А.Қ. Жұмабекованың « Аударма теориясы»мен «Аударматанудың негіздері» [6], Ш.Т.Сауданбекованың «Аударма теориясы және практикасы» [7], А.Б. Ахметованың « Аударма теориясы мен тәжірибесінің негіздері» [8], Ж.А. Жақыповтың «Аударма анықтамалығы» [9], Д.Рақымбекова мен Р.Абисалықованың «Аударма теориясы мен тәжірибесі» [10] т.б. оқулықтары мен оқу құралдарының жариялануының өзі қазіргі таңда аударматануға деген қызығушылықтың артқандығының айқын көрінісі.
Тәуелсіздік жылдары аударма теориясы мен тәжірибесіне арналған докторлық және кандидаттық диссертацияларда қорғалды. Мәселен, Г.Ж. Болатованың «Абайдың «Қара сөздерін» орыс тіліне аудару», К.Ә. Әлпейісованың «Қазақ тілінен орыс тіліне ілеспе аударма жасау заңдылықтары», Б. Керімбекованың «Фариза Оңғарсынова поэмаларындағы идеялықкөркемдік ізденістер», Г.Т. Тусупованың «Ағылшын тіліндегі әңгімелерді қазақ тіліне аударудағы мерзімді ұстанымдар» т.б. аударматанудың өзекті мәселелеріне арналған.

6D020700 - Аударматану мамандығы бойынша соңғы кездері $\mathrm{PhD}$ докторлық диссертациялар да қорғалды. К.А.Аубакированың «Жүсіпбек Аймауытұлының аудармалары: түпнұсқа және мәдени-көркеминтеграция», М.Ескиндированың «Қазақстандағы ауызша аударма әдіснамасы», К.А. Альпеисованың «Қазақ тілінен орыс тіліне ілеспе аударма үлгілері (саяси дискурс негізінде)», А.Т.Баекееваның «Қазақ тіліндегі тау-кен терминологиясының қалыптасуы және ағылшын, орыс тіліне аударылу ерекшеліктері», А.Жапаровның «Абай поэзиясындағы метафора және оның орыс, ағылшын тілдеріндегі аудармалары: салыстырмалы талдау», А.У.Жусупованың «А. Нұрпейісовтің «Қан мен тер» трилогиясындағы этномәдени сәйкестіктің аударылу мәселесі», Н.Жұмайдың «Жазушы тілдік тұлғасының аудармада берілуі (О. Бөкей шығармалары негізінде)», Қ. Кенжеқанованың «Саяси дискурстың прагмалингвистикалық және когнитивтік компоненттері (қазақ тіліндегі мерзімді басылымдар материалдары бойынша)», М.Т.Кожаканованың «Абай Құнанбаевтың әдеби мұрасын әлемдік тілдерге аудару (рецепция, интерпретация)», А.М. Төлеубаеваның «Ә.Нұрпейісовтің «Соңғы парыз» шығармасындағы метафоралардың лингвомәдени лакуналар ретінде аударылу ерекшеліктері», М.Ж. Ескендированың «Методология устного перевода в Казахстане», А.Б.Абағанның «Корей фразеологизмдерін қазақ тіліне аударудың лингвомәдени қыры (корей фильмдерін аудару тәжірибесінен)», Н.О.Отегеннің «Қазақша дәстүрлі әңгіме және оның ағылшын тіліндегі стереотиптік баламалары», т.б

Әл-Фараби атындағы Қазақ ұлттық университетінің филология факультетіндегі «Шетел филологиясы және аударма ісі» кафедрасының оқытушы-профессорлар құрамы да аударматану ғылымының дамуы мен өркендеуіне үлес қосып келеді. Сонау 1996 жылы ашылған кафедрада 
«Аударматану мамандығына кіріспе», «Аударма теориясы», «Аударма тәжірибесі», «Синхронды аударма», «Көркем аударма», «Халықаралық ұйымдардағы ауызша аударма», «Қазіргі замандағы аударматану», «Герменевтика және аударматану», «Аудармашыға арналған онлайн сөздік құру », «Поэтикалық аударма», «Аударматану және смарт технологиялар», «Жазбаша аударма типологиясы», «Аудармадағы баламалық деңгейлері теориясы», «Медиалингвистика және шет тілі», «Екінші тілді меңгеру теориясы», «Академиялық мақсаттағы шетел тілі» т.б. іргелі пәндерден дәрістер өткізіледі.

Қазіргі уақытта кафедрада 39 оқытушы: 5 ғылым докторы, 14 ғылым кандидаты, $5 \mathrm{PhD}$ докторы, 12 магистр және 3 оқытушы жұмыс істейді. Жыл сайын кафедра ұжымы ондаған оқу құралдарын, әдістемелік нұсқаулар, хрестоматиялар мен сөздіктер, жүзден аса ғылыми мақалалар жариялайды. Бұл ғылыми басылымдарда аударманың қыр-сырлары жан-жақты қарастырылады, болашақ аудармашыларды дайындауға арналған тұжырымдар беріледі. Ж.Д.Дәдебаевтың «Абайдың антропологизмі», С.С.Ашимханованың ағылшын тіліндегі «История литературы страны изучаемого языка. Английская литература от романтизма до наших дней», Т.О.Есембековтің «Көркем мәтін поэтикасы», «Көркем мәтін және аударма», А.С.Тараковтың «Аударма психологиясы мен мәдениеті», «Аударма әлемі», «Ауызша аударма», «Аудармашының кәсіби қызметінің негіздері» оку құралдары, Л.Ж.Мұсалының «Аудармашының кәсіби машығы», «Көркем тәржіма тәжірибесі бойынша практикум», «Көркем мәтін және аударма», С.Д.Сейденованың «Практикум по письменному переводу», «Аударматанудың заманауи мәселелері», Г.Қ.Қазыбектің «Аударматануға кіріспе», «Аударма теориясы мен тәжірибесі» т.б. оқулықтары мен оқу құралдары Қазақстандағы аударматану мамандығы бойынша білім алатын студенттер мен магистранттарға, докторанттарға арналған.

Тәуелсіздік жылдары кафедра оқытушыларының ғылыми мақалалары АҚШ, Ұлыбритания, Германия, Грекия, Венесуэла, Словения, Венгрия, Қытай, Түркия, Ресей, Қырғыстан, Өзбекстан сияқты елдердің ғылыми басылымдарында үзбей жарияланып келеді.

Тәуелсіздік алғаннан бастап филология факультетінің Түркияның, Қытайдың, Ресейдің, АҚШ-тың, Канаданың, Венгрияның, Қырғызстанның, Өзбекстанның ірі ғылыми және білім беру орталықтарымен ғылыми ынтымақ- тастығы жолға қойылды. Шетел филологиясы және аударма ісі кафедрасының M.В. Ломоносов атындағы Мәскеу мемлекеттік университетінің аударма теориясы мен лексикография кафедрасымен, Мәскеу лингвистика және аударма институтының аударма кафедрасымен, Волгоград университетінің аударма теориясы және практикасы кафедрасымен, PETERS ғылыми-баспа орталығымен (Бельгия), Ресейдің Халықтар достығы университетінің тиісті құрылымдық бөлімдерімен, Ресей-Тәжік (славян) университетімен, Стамбул Мәдениеті университетімен, Шыңжаң университетімен (Қытай) байланысы бар.

Кафедра оқытушылары қазақ ақын-жазушыларының өзге тілдерге аударылу тарихына да байланысты дәрістер өтеді. Мысалы, А.Құнанбайұлының, М.Әуезов, О.Бөкеев, Б.Соқпақбаев, М.Мақатаев, Ә.Кекілбаев, Ә.Нұрпейісов, О.Сүлейменов т.б. Дәрістерде түпнұсқа мен аударма нұсқаларының арасындағы жетістіктер мен кемшіліктер сараланады. Болашақ аудармашыларға аударма бірліктері туралы қызықты да нақты мәліметтер беріледі, талдаулар жүргізіледі. Кафедра оқытушылары өз дәрістерінде аударматану ғылымына байланысты жазылған шетелдік ғалымдардың да ғылыми зерттеулері мен оқулықтарын пайдаланады. Көбінесе дәрістер мен семинар сабақтары ағылшын, неміс, француз, испан тілдерінде оқытылатын айта кеткеніміз дұрыс. Кафедра оқытушылары отандық еңбектер мен бірге алыс жақын шетелдік ғалымдардың еңбектерін де өз дәрістерінде ұтымды пайдаланады. Мысалы, "Achieving consilince: translation theories and practice» [11], «Reflection on translation theory: selected papers 1993-2014. Chesterman, Andrew» [12], «The development of translation competence: theories and methodologies from psycholinguistics and cognitive science» [13], «William Faulkner's Later Novels in German: a Study in the Theory and Practice of Translation» [14].

Филология факультеті жыл сайын дәстүрлі «Филология, лингводидактика және аударматану: өзекті мәселелері мен даму тенденциялары» атты Халықаралық ғылыми және оқу-әдістемелік конференция ұйымдастырады. Конференция мына бағыттар бойынша жүргізіледі: Тілдік емес ЖОО-дағы шет тілдерін оқыту мәселелері; Болашақ мұғалімдер мен аудармашыларды кәсіби даярлаудың теориясы мен әдістемесі; Орта мектеп пен ЖОО-да шет тілдерін оқытудың заманауи технологиялары; Тіл білімі мен аударманың жалпы 
теориялық және жеке мәселелері; Әлемнің тілдік бейнесі және мәдениеттердің өзара байланысы; Аударманың лингвистикалық аспектілері. Конференцияға алыс және жақын мемлекеттердің беделді аударматану ғалымдары мен аудармашылары қатысады. Конференция материалдары жеке жинақ болып жарияланады. Бұл конференциялардың негізгі мақсаты қазіргі кездегі аударматану ғылымындағы жаңа көзқарас, жаңа бағыттар, аударма жасаудың жаңа әдістері т.б.туралы ойлармен бөлісу.

Соңғы кездері аударматану туралы ұжымдық монографиялар, хрестоматиялар, анықтамалықтар мен сөздіктер, ғылыми мақалалар жарық көрді. Мәселен, Э. Дүйсенованың «Адам өлшемі бойынша: қазақ және орыс сөздіктеріне арналған материалдар, А.Ж. Жақсылықов, T.О. Есембеков, Г. Қазыбектің «Аударматану бойынша библиографиялық көрсеткіш» анықтамалығы, Г. Қазыбектің «Аударма тәжірибесі» хрестоматиясы, Ә. Тараковтың “Аударматанудың заманауи мәселелері”. Кафедра оқытушылары М. Аймағамбетованың «Қазақстан медиадискурсының когнитивті стратегиясы», Г.Акимбекованың «Фразеология - гендерлік стереотиптердің қайнар көзі (ағылшын тіліндегі материалдардың негізінде)», С.Ашимханованың «М. Жұмабаев поэзиясындағы ұлттық нақыштағы қаратпа сөздердің аударылу ерекшеліктері (түрік, орыс, ағылшын тілдері)», И. Әзімбаеваның «Фразеологизмдердің этномәдени даралығы және олардың аудармадағы сәйкестігі», Г. Габдкаримованың «Аударма - тілдік және мәдениет аралық құрал», Ж.Дәдебаевтың «Абайдың “Қақтаған ақ күмістей кең маңдайлы” өлеңін орыс ағылшын тілдеріне аударылу мәселелері», Қ.Кенжеқанованың «Қоғамдық эвфемизмдердің маңызы және олардың британдық және қазақстандық баспасөздегі қолданысы», С.Новикованың «Неміс мәтіндеріндегі терминология аудармасының ерекшелігі», А.Жапарованың «Метафораның тарихи-философиялық негіздері», «Когнитивті лингвистикадағы метафора» т.б. ғылыми мақалалары аударматану ғылымының өзекті мәселелеріне арналған .

Ал Scopus деректер базасы жарияланымдарында жарық көрген Э.Сүлейменова мен М.Аймағамбетованың «Biz birgemiz, или Еще раз о диверсификации русского языка в Казахстане», Э.Жанысбекованың «Myth and Kazakh Mythology: Retrospective Analysis and Prospects of Research», О.Куратованың «The Professionally-Oriented Foreign Language Teaching at
Non-Linguistic Faculties of Universities», «Scientific and Methodological Maintenance of Advisor's Activity as a Basis of the Corporate Culture of the Future Teachers of Foreign Languages», Г.Қазыбектің «Cognitive poeticsas a translator's perception instrument of time and space conceptsin», С.Ашимханованың «Russian-Kazakh literary relations: The Influence of Russian realism on the development of A. Nurpeisov's writing», С.Ашимханова мен А.Алпысбаеваның «Translation of the Culture-Specific Items in Jumabayev's "Men Jastarğa Senemin" into English and Russian», С.Сейденова мен Ж.Манапбаеваның «The treatment of realia in the translations of Smagul Yelubay's novel “Ak Boz Uy”», Ә.Тараков, И.Әзімбаева және Ж.Абдуллаеваның «Translation problems of phraseological units (on the basis of M. Auezov's novel "the Way of Abai")», А.Жапарованың «The functional characteristics of a metaphor in Abay's poems», "The conceptual metaphor in Abay Kunabayev's poetics», «Translating the Kazakh poet Abay», А.Айтжанованың «Linguodidactics as a methodological foundation of foreign language teaching», Г.Ерсултанованың «Cognitive lingua-cultural methodology as a universal model for the formation of the language personality», Д. Қарағойшиева, Г. Искакова, С.Бектемировалардың «Intonation of Kazakh and English languages», Л.Мирзоеваның «Cognitive procedures as an instrument of translation process analysis» және «Воссоздание семантических и прагматических характеристик обряда в турецко-русском переводе (на материале романа О. Памука «Имя мне - Красный» и его русской версии)»ғылыми мақалалары аударматану мамандығында білім алатын тәлімгерлерге арнайы жазылған құнды туындылары.

Француз аударматанушысы Э.Кари: “Аударма ұғымы, шындап келгенде, өте күрделі ұғым. Бұл аударманың біздің заманымызда кездесетін түрлерінің көптігінен ғана туындап отырған жоқ. Ол аударманың ғасырлар бойы әрдайым өзгеріп отыруына да байланысты құбылыс. Мүмкін, нақ осы жағдай өзінікінен бұрын берілген анықтамалармен не келісіп, не оны жоққа шығарып отырған ғалымдардың өз ойларын тұжырымдауын қиындататын да болар", - деп айтқандай, университеттің оқытушы-профессорлар құрамы болашақ аудармашыларға сапалы білім беруде еліміздің алдыңғы қатарлы жоғары оку орындарының бірі деп мақтанышпен айта аламыз. Қазіргі заман дамуына сай университет оқытушылары да аударманың теориясы мен тәжірибесіне 
арналған дәрістерінде озық технологияларды да қолдануға машықтанды. Университетте аудармашыларға арналған кабинеттер мен зертханалар ашылды.

Бұдан әл-Фараби атындағы Қазақ ұлттық университетіфилология факультетініңоқытушыпрофессорларының Тәуелсіз Қазақстандағы аударматану ғылымының өсіп-өркендеуіне өлшеусіз үлес қосып келе жатқандығының айқын көрінісі деп есептейміз.

\section{Қорытынды, тұжырымдар}

Тәуелсіз Қазақстанда аударматану ғылымының ахуалының едәуір дамығаны байқалады. Қазақстан Республикасы Үкіметі тарпынан, Қазақстан Республикасы Білім және ғылым министрлігінен, Әл-Фараби атындағы ҚазҰУ Басқарма төрағасы - Ректор Ж.Қ.Түймебаевтың тараптарынан болсын аударма ғылымына, аудармашылар мамандығын даярлайтын оқытушы-профессорлар құрамына да елеулі қолдау көрсетіліп келеді. Тәуелсіздік алғаннан бері әлем тілдерінің шығармалары қазақ тіліне тікелей аударыла бастады. Қазақстан ақынжазушыларының шығармалары керісінше басқа тілдерге үзбей аударылып келеді. Аударматану ғылымының жаңа белестері ашыла бастады.

Қазіргі кезде Қазақстанда түрлі тәуелсіз аудармашылар бірлестіктері мен қауымдастықтар құрылған. Мысалы, «Кәсіби аудармашылар мен аударма компаниялар қауымдастығы», «Қазақстан Аудармашыларының Тәуелсіз Қауымдастығы» т.б. Олардың негізгі қызметтері құжаттарды, шағын мәтіндерді аудару. Біздің ойымызша, әл-Фараби атындағы Қазақ ұлттық университетінің жанынан «Көркем аудармашылар Одағын» құрып, негізінен Елбасының жолдауларында айтылып жүрген әлем әдебиетінің озық үлгілерін қазақ тіліне немесе қазақ ақын-жазушыларының шығармаларын тікелей ағылшын, неміс, француз тілдеріне аударылып жарыққа шығып отырса деген ниеттеміз. Сонда ғана көркем әдебиеттің аударылу сапасын тексеруге мүмкіндік туады. Көркем әдебиетті аударатын аудармашылардың мақсаты мен міндеттері айқындалады.

Халықаралық аудармашылар федерациясын 1953 жылы Пьер-Франсуа Кэйет Париж қаласында құрған болатын[15]. Қазіргі таңда федерация елуден астам елдің аудармашылары, шамамен 80 мыңнан астам кәсіби аудармашылар мен 100-ден аса аудармашылар қауымдастығын біріктіреді. 1991 жылы Халықаралық Аудармашылар Федерациясы 30 қыркүйек күнін Халықаралық аудармашылар күні деп бекітті. Халықаралық аудармашылар федерациясының ең жоғарғы органы Халықаралық конгресс үш жыл сайын жиналыс жасап отырады. Федерацияның негізгі мақсаты аудармашылар мамандығының кәсіби шеберлігін арттыру болып табылады. Біздің университетімізде аудармашылар дайындайтын мамандықтар бар, оқу кабинеттері мен қазіргі заманға сай құралжабдықтармен қамтамасыз етілген. Келешекте университет ғалымдарының осы Халықаралық аудармашылар федерациясының құрамына кіру мақсатында қызмет атқару. Қазіргі таңда университет тарапынан аударма мамандарына орасан зор қолдау көрсетіліп келе жатқандығын мақтанышпен айтуымызға болады.

Тәуелсіз Қазақстандағы аударматану ғылымының өркендеуіне осылайша әл - Фараби атындағы Қазақ ұлттық университетінің білікті аудармашылары өз үлестерін қосады деген үміттеміз.

\section{Әдебиеттер}

Азаматтыққа адалдық: әдеби сын мақалалар, зерттеулер, толғаныстар / С. Әшімбаев. - Алматы: Раритет, 2007. - 334 б.

Сатыбалдиев Ә. Рухани қазына. Жазушы,1987. - 171 б.

Мемлекет басшысының «Болашаққа бағдар: рухани жаңғыру» атты мақаласы. 2017 жылғы 12 сәуір. akorda.kz

Алдашева А.М. Аударматану: лингвистикалық және лингвомәдени мәселелер. - Алматы, 1999. - 161 б.

К. Әлпейісова Ә. Ілеспе аударма: таным мен тәжірибе: Оку құралы. - Алматы: «Арда», 2018. - 1526.

Жұмабекова А.Қ. Аударматанудың негіздері: Оку-әдістемелік құрал. - Алматы, 2012. - 296 б

Сауданбекова Ш.Т. Аударма теориясы және практикасы. Оку құралы. - Алматы: «Қазақ университеті» 2015. - 90 б.

Ахметова А.Б. Аударма теориясы мен тәжірибесінің негіздері (қазақ және орыс тілдеріндегі) дәріс курсының оқуәдістемелік құралы. - Павлодар: ПМПИ, 2014. - 90 б.

Жақыпов Ж.А. Аудармашы анықтамалығы. - Алматы: Сардар, 2009. - 176 бет.

Рақымбекова Д., Абисалықова Р. Аударма теориясы мен тәжірибесі: Оқу құралы. - Астана: Фолиант, 2012. - 160 бет.

Achieving consilince: translation theories and practice. Cambridge Scholars Publishing., 2016. - $230 \mathrm{p}$

Reflection on translation theory: selected papers 1993-2014. Chesterman, Andrew. - John Benjamins Publishing Company., 2017. $-132 \mathrm{p}$. 
The development of translation competence: theories and methodologies from psycholinguistics and cognitive science. Cambridge Scholars Publishing., 2014. - 322 p.

William Faulkner's Later Novels in German: a Study in the Theory and Practice of Translation. Boecker, Eberhard. - De Gruyter, Inc., 2017. -248 p.

https://www.fit-ift.org/International Federation of Translators

\section{References}

Achieving consilince: translation theories and practice. Cambridge Scholars Publishing., 2016. - 230p.

Akhmetova A.B. Audarma teoriyasy men tazhirbiesinin negizderi (kazak zhane orys tilderindegi) daris kursynyn oku-adistemelik kuraly.[Theory and practice of translation studies(kazakh and russian languages)]-Pavlodar:PMPI, 2014.-90p. (In Kazakh)

Aldasheva A.M. Audarmatanu: lingvistikalyk zhane lingvomadeni maseleler [Translation Studies: linguistic and linguocultural issues.].- Almaty, 1999.-161p. (In Kazakh)

Azamattykka adaldyk: adebi syn makalalar, zertteuler, tolganystar [Loyalty to citizenship: literary criticism, research, reflections]. /S.Ashimbaev.-Almaty:Raritet, 2007.-334b. (In Kazakh)

https://www.fit-ift.org/International Federation of Translators

K.Alpeisova A. Ilespe audarma: tanym men tazhirbie maseleler [Translation Studies: linguistic and linguocultural issues.]: Oku kuraly.-Almaty: «Arda», 2018. - 152 p. (In Kazakh)

Memleket bashysynyn «Bolashakka bagdar: rukhani zhangyry» atty makalsy.April 12, 2017 akorda.kz. (In Kazakh)

Rakymbekova D., Abisalykova R. Audarma teoryasy men tazhirbiesy [Theory and practice of translation studies]:Oku kuraly.Astana:Folliant, 2012.-160 b. (In Kazakh)

Reflection on translation theory: selected papers 1993-2014. Chesterman, Andrew. - John Benjamins Publishing Company., 2017. - 132p.

Satybaldiev. Rukhani kazyna [Spiritual treasure]. Zhazushy, 1987.-171p. (In Kazakh)

Sh.T.Saudanbekova. Audarma teoryasy zhane praktikasy. [Theory and practice of translation studies]Oku kuraly.Almaty «Kazakh universiteti» 2015. - 90 б. (In Kazakh)

The development of translation competence: theories and methodologies from psycholinguistics and cognitive science. Cambridge Scholars Publishing., 2014. - 322p.

William Faulkner's Later Novels in German: a Study in the Theory and Practice of Translation. Boecker, Eberhard. - De Gruyter, Inc., 2017. - 248p.

Zhakypov Zh.A. Audarmashy anyktamalygy [Translator's directory]. Almaty: Sardar, 2009.-176p. (In Kazakh)

Zhumabekova A.K.Audarmatanudyn negizderi[Basis of Translation studies]:Oku adistemelik kural.-Almaty, 2012.-296p. (In Kazakh) 